\title{
Haderslev byhistoriske Arkiv
}

\section{Af Olav Christensen}

I de senere år er der ved oprettelsen af by- og egnshistoriske arkiver sket en nydannelse inden for dansk arkivvæsen. Det f $\varnothing$ rste af disse arkiver blev grundlagt i Fåborg i 1937, og senere er der rundt om i landet vokset en 25 andre frem, hvoriblandt som det f $\phi$ rste og hidtil eneste i S $\phi$ nderjylland Haderslev byhistoriske Arkiv. Selv om de byhistoriske arkiver således kun er unge af år, har de på mange måder vist deres betydning, og der er herved inden for den historiske forskning skabt et værdifuldt led, der vil få stedse st $\varnothing$ rre betydning, navnlig for lokal- og personalhistorien.

Et lokalhistorisk arkiv vil kunne oprettes for en enkelt by, for en bestemt egn evtl. for et helt amt, og dets opgave ligger først og fremmest $i$ at indsamle og derved for eftertiden at sikre den store mængde af værdifuldt arkivmateriale, som findes rundt om i private hjem og i lokale foreningers arkiver, og $i$ at skabe billedsamlinger.

Dette arbejde ligger uden for de store statsarkivers virkefelt, ligesom de heller ikke vil kunne overkomme denne opgave eller have de samme muligheder for at gennemf $\phi$ re den med et heldigt resultat, som lokalkendte personer vil det. Men de lokalhistoriske arkiver har desuden endnu en vigtig opgave at nyskabe arkivalsk stof, f. eks. ved registrering af avisernes righoldige og værdifulde indhold, ved indsamling af selvbiografier, ved optagelse af et stemmearkiv og ved gennemfotografering af byens eller egnens daglige liv, som det former sig til hverdag og fest.

De fleste byer tæller blandt deres borgere folk, der har så megen historisk sans, at de vil kunne forstå betydningen af et sådant arkivarbejde og også, når blot een mand vil tage initiati- 
vet, vil vare rede til at gå ind i dette arbejde. Man må imidlertid gøre sig klart, at et sådant arbejde tager sin tid; men at det også er berigende og på sin måde underholdende.

I Haderslev startede arbejdet i 1946. En kreds af borgere indsendte et andragende til byrådet om at støtte ei sådant arkiv, og $\mathrm{i}$ sit den 17. december 1946 afholdte møde vedtog byradet derefter ikke alene at st $\phi$ tte arbejdet $\emptyset$ konomisk og at overlade arkivet rådstuearkivets lokaler til foreløbig brug, men viste også sin interesse og forståelse for sagen ved af sin midte at udpege to medlemmer til at tiltræe arkivets bestyrelse, der blev fastsat til at skulle bestå af mindst ni mand, og som iøvrigt supplerer sig selv. Som formand og sekretær valgtes fuldmægtig Olav Christensen, der siden har forestået arbejdet.

Arkivets formålsparagraf oplyser, at Haderslev byhistoriske Arkiv er en selvejende institution, hvis formål er at samle skrevne og trykte kilder samt billeder vedrørende Haderslev by, dens borgere og institutioner samt eventuelt at udgive lokalhistoriske skrifter.

I begyndelsen af året 1947 trådte arkivet derefter frem for offentligheden, idet der udsendtes et opråb til byens borgere og foreninger med opfordring til at støtte arbejdet ved at overlade arkivet arkivmateriale og billeder af enhver art.

I den forløbne halve snes år er der til arkivet indgået omkring 450 gaver fra en enkelt ting til stø̆rre samlinger af arkivalier og billeder. Blandt giverne træffes en lang række enkelt personer fra alle samfundslag og en del foreninger, der har forstâet værdien af at kunne få forhandlingsprotokoller og andre arkivalier mere sikkert opbevaret end hos skiftende formænd og sekretærer, hvor faren for, at de skulle gå til grunde, er betydelig større. Ved en pulterkammerrydning under besættelsen oplevede jeg f. eks. et grelt eksempel på, hvor ligegyldigt en ganımel protokol kan blive behandlet. Haderslev Handelsforenings ældste forhandlingsprotokol, der går tilbage til 1844, var ved en oprydning havnet $i$ en bunke, der skulle i papirmøllen, og kun et lykkeligt tilfælde medf $\phi$ rte, at den blev reddet.

Foreningens arkivalier vil altid være af historisk værdi, idet de giver gode bidrag til personal- og kulturhistorien, men for 


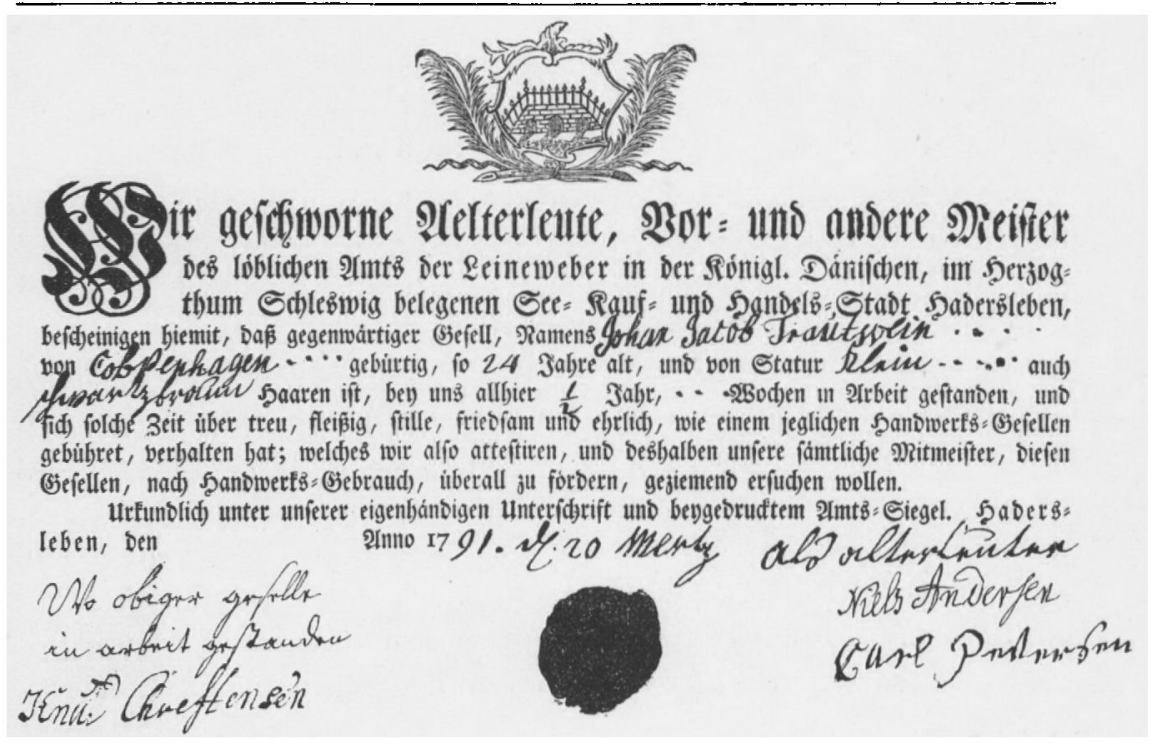

Et $i$ sig selv ubetydeligt dokument kan, nar der ikke findes andre arkivalier bevaret vedrorende et bestemt emne, give vardifulde oplysinger. Ovennæunte anbefaling fra vaverlavet giver os saledes navnene pa to oldermand fra 1791 .

S $\varnothing$ nderjyllands vedkommende vil de endda have en særlig betydning, idet der for næsten alle foreningers vedkommende vil være tale om, at de nationale brydninger afspejler sig i deres virke.

Det er ikke meningen, at alle modtagne gaver skal opremses her, men nogle enkelte ting skal dog fremdrages, idet de giver gode eksempler på, hvad et byhistorisk arkiv kan og b $\phi \mathbf{r}$ samle. Arkivet har blandt andet modtaget forhandlingsprotokoller fra

Haderslev Håndvarkerforening 1857-1948,

Haderslev Skydeselskab 1857-1925,

Haderslev Sangforening 1881-1940,

Snedkerforbundet 1902-1952,

Haderslev Ungdomsforening 1908-1934,

Kommunalforeningen 1909-1914,

Kolonihaveforeningerne $\gg$ Ryesminde $\ll, ~ *$ Virkelyst $\ll$ og $\gg$ Bellah $\phi j \ll 1924-34$ og 1938-53,

Femtende Juni-foreningen 1927-48, og nævnes skal også

Dansk Ungdomssamvirkes arkiv 1940-46. 
Mange private har også betænkt arkivet med gaver $i$ form af sk $\phi$ der, svendebreve, vandreb $\phi g e r$ og breve samt billeder dels af personer og dels topografiske, blandt andet et par portratalbums med samlinger af portrætter. Det ene, et særligt smukt album med s $\varnothing$ lvbeslag og s $\phi$ lvinitialer, rummer billeder af fremtræedende danske fra Haderslev by og opland og er skænket advokat Carl Salicath og hustru i 1872, da de efter at have opbrugt deres formue, måtte fortrække fra Sønderjylland, fordi Salicath ikke $\phi$ nskede at aflægge ed til de tyske myndigheder, og det andet, der barer en sølvplade med indskriften: Haderslev Sangforening 12. Maj 1876, med billeder af sangerne.

En værdifuld gave fik arkivet fra apoteker Lausten Hansen, der har skænket Hjorte Apotekets meget velbevarede arkiv, som går tilbage til $1583 \mathrm{og}$ foruden apotekernes originale privilegier fra 1660 til 1920 rummer en række andre arkivalier af lokal- og kulturhistorisk værdi.

Gaverne indf $\phi$ res $i$ en gaveprotokol, hvor hver gave far sit nummer med anførelse af giverens navn og bopæl samt en specifikation over de skænkede ting, der samtidig forsynes med gavens nummer, så man til enhver tid kan finde frem til, hvad en bestemt person har skænket arkivet, eller til den, som har overladt arkivet en bestemt gave.

Det indsamlede materiale fordeles i tre hovedgrupper, en topografisk, en personlig og en saglig eller kulturhistorisk afdeling.

Den topografiske afdeling indeholder alt, hvad der har tilknytning til hele byen eller en bestemt lokalitet, og rummer optegnelser om byens historie, ejendomspapirer, fotografier og fotografiske negativer af gader og ejendomme samt bykort og matrikelskort m. v.

Den personalhistoriske afdeling rummer oplysninger om enkelte borgere og slægter såsonı dagbøger, breve, personlige papirer (borgerbreve, vandreb $\emptyset g e r$, svendebreve, diplomer o.s.v.) og stamtavler samt billeder og fotografiske negativer af enkelt personer eller grupper af personer, såfremt disse sidste ikke på grund af særlig tilknylning til en forening b $\phi r$ henf $\emptyset$ res til den saglige afdeling. 
Den saglige eller kulturhistoriske afdeling rummer alle forcningsarkivalier, forhandlingsprotokoller, regnskaber og korrespondancer samt arkivmateriale vedrørende handel, håndværk og industri, om genforeningen, besættelsestiden og andre st $\varnothing$ rre begivenheder $\mathrm{m}$. v. Også til denne afdeling er der knyttet billedstof, f. eks. byens f $\phi$ rste bil, Haderslev Amts Jernbaner - de $s \phi n-$ derjydske småbaners billedmateriale er ved at blive sjældent, og det er derfor på høje tid at få det samlet - markeder, optog af enhver art $m$. $v$.

Samlingerne registreres på kartotekkort, og der foretages krydshenvisninger, men alt dette ligger uden for denne artikels rammer og skal derfor ikke omtales nærmere. Det kan om opbevaringen måske dog være grund til at nævne, at proveniensprincippet, der kræver, at et aktstykke forbliver på sin oprindelige plads $i$ et embedes eller en persons arkiv, og som er enerådende ved statsarkiverne, kun til dels er gældende ved de lokalhistoriske arkiver. Det vil nemlig ofte være hensigtsmæssigt at samle ting fra forskellige samlinger vedrørende et bestemt forhold i et nyt læg, f. eks. kan der på denne måde opbygges en samling minder fra besættelsestiden, hvor der i Haderslev bl. a. er samlet: lokale udgaver af Frit Danmark, et par andre lokale illegale blade, illegale og legale lokale lobesedler, abonnementslister til illegale blade, billeder $\mathrm{m}$. $\mathrm{m}$.

Haderslev byhistoriske Arkiv har imidlertid udover indsamlingen også taget en enkelt anden opgave op, idet det takket være en bevilling fra arbejdsministeriet er lykkedes som beskæftigelsesforanstaltning at påbegynde en registrering af Dannevirke, Sønderjyllands æeldste avis, der rummer et så righoldigt stof ikke alene for lokal- og personalhistorien, men i lige så høj grad for vor nationale historie. Det vil imidlertid tage år at få udskrevet et sådant kartotek, der vil komme til at omfatte mange tusinde kort, men der vil da også til den tid være åbnet adgang til et historisk kildemateriale, som det i dag nærmest er umuligt at få udnyttet.

Arkivet har desuden i 1956 kunnet udsende sin forste publikation $i$ en forhåbentlig lang skriftrække, en bibliografi over Haderslev litteratur. Arkivet mødte ved denne lejlighed som 
iøvrigt en enestående velvilje og forståelse fra alle sider i byen, idet det lykkedes at samle de nodvendige pengemidler sammen ved gaver fra kommunen samt institutioner og større næringsdrivende.

Endnu ligger der dog mange opgaver, som presser sig på for at blive løst. En fortsat indsamling af arkivalier og billeder, oprettelse af en samling af selvbiografier, båndoptagelser af Haderslev-målet, inden dette fuldstæendig forsvinder, og en gennemfotografering til dels på film af byens liv, af byrådets møder, grisemarkedet, torvedagen, af byen i fest og hverdag. Det hører dog fremtiden til, men skal løses en gang. 